\title{
PENGEMBANGAN KAPASITAS PEGAWAI UNTUK MEWUJUDKAN GOOD GOVERNANCE PADA KANTOR DINAS KEPEMUDAAN DAN OLAHRAGA KOTA PALEMBANG
}

\author{
Dian Novita Fajar Sari \\ Sekolah Tinggi Ilmu Administrasi (STIA) Satya Negara Palembang \\ Email : novitadian538@gmail.com
}

\begin{abstract}
ABSTRAK
Abstract: Capacity Building of Public Servants to Attain Good Governance (Study at The Office of youth and sports senvices Kota Palembang). The realization of good governance needs professional and competent public servants. Early step that shall be taken by local government is capacity building of public servants in every public organization in the local. One public organization that is Local Employment Agency of Palembang city. Result of research indicates that capacity building of public servants at Local Employment Agency of Palembang City in general has been quite well. Employee transparency for information openness is not working optimally. Employee responsiveness to administrative senvice is adequate. Employee equality in delivering service is sufficient. Capacity building of public servants must be supported by enthusiastic leadership which drives employee and collective commitment based on work contract and employee agreement. Employee must be made understood through socialization, internal session or even internal regulation.
\end{abstract}

Keyword: capacity building, good govemance

\section{Pendahuluan}

Kapasitas sumberdaya aparatur sangat terbatas pada sebagian besar daerah di Indonesia menjadikan program capacity building sebagai salah satu agenda utama yang harus dilakukan (Warsito dan Yuwono, 2003, h.2). Penerapan prinsip-prinsip good governance dianjurkan agar adanya desentralisasi memungkinkan pemerintah daerah memberikan yang terbaik bagi masyarakat di daerah. Oleh karena itu, langkah awal yang harus diambil oleh pemerintah daerah adalah melaksanakan pengembangan kapasitas (capacity building) yang saat ini direkomen-dasikan dalam rangka pembenahan aparatur, termasuk aparatur daerah. Menurut Yuwono dalam Warsito dan Yuwono (2003, h.1), capacity building memberikan sebuah harapan yang baik, khususnya dalam kerangka mewujudkan tujuan penyelenggaraan pemerintahan, yaitu dalam rangka peningkatan efektivitas dan efisiensi manajemen publik menuju realisasi tujuan yang diharapkan. Dimana, salah satu poin capacity building menunjuk pada konsep good govemance dan sudah dikembangkan dengan baik oleh United Nation Development Program (UNDP-PBB).

Berdasarkan isu-isu strategis menggambar-kan bahwa dari analisis lingkungan internal dan ekstemal, isu strategis pembangunan Kota Palembang. Untuk diperhatikan adalah Good Govemance. Berdasarkan penelitian terdahulu oleh Artika (2014, h.6), dan Prasetia (2014, h.4) bahwa terdapat beberapa permasalahan berkaitan dengan peran Dinas Kepemudaan dan Olahraga Kota Palembang dalam melaksanakan tupoksinya. Sedangkan semakin hari tuntutan akan good governance semakin mendesak. Oleh karena itu, 
Dinas Kepemudaan dan Olahraga Kota Palembang dituntut untuk selalu berupaya keras mengembangkan kemampuan dan meningkatkan kinerja pegawai internalnya agar lebih berkompeten dan profesional dalam setiap pelayanan prima dari semuaaspek.

Dinas Kepemudaan dan Olahraga Kota Palembang melakukan pengembangan kapasitas terhadap pegawainya juga dimaksudkan untuk penguatan organisasi dan sebagai salah satu upaya membentuk sistem kepemerintahan yang baik (good governance). Mengingat banyaknya aparatur daerah yang harus dilayani dan dikelola oleh pegawai di Dinas Kepemudaan dan Olahraga Kota Palembang, maka mengharuskan instansi tersebut melakukan upaya pengembangan kapasitas (capacity building) terhadap pegawai intemalnya secara berkelanjutan agar mampu dan profesional dalam melaksanakan penyelenggaraan pemerintahan secara baik serta mengaktualisasikan prinsip-prinsip good governance. Oleh karena itu, penulis memfokuskan masalah pengembangan kapasitas melalui peningkatkan pengetahuan dan ketrampilan pegawai Dinas Kepemudaan dan Olahraga Kota Palembang dan penerapan dari good governance itu sendiri.

\section{Tinjauan Pustaka}

\section{Administrasi Publik}

Menurut Thoha (2008, h.67), pemahaman istilah public seperti yang dilekatkan sebagai predikat pada istilah administration hendaknya dipahami sebagai predikat terhadap proses kepemerintahan (governance). Lebih lanjut, Thoha (2008, h.94) mendefinisikan administrasi publik menupakan suatu kajian yang sistematis dan tidak hanya sekedar lukisan abstrak akan tetapi juga memuat perencanaan realitas dari segala upaya dalam menata pemerintahan menjadi kepemerintahan yang baik (good governance). Administrasi Publik menurut Chandler dan Plano sebagaimana dikutip oleh Indradi (2010, h.114) adalah proses dimana sumberdaya dan personel publik diorganisir dan dikoordinasikan untuk memformulasikan,mengimplementasikan, dan mengelola keputusan-keputusan dalam kebijakan publik.

\section{Pengembangan Kapasitas}

Morgan dalam Milen (2006, h.14) mendefinisikan kapasitas sebagai kemampuan, ketrampilan, pemahaman, sikap, nilai-nilai, hubungan, motivasi, sumberdaya, dan kondisi-kondisi yang memungkinakan setiap individu, organisasi, jaringan kerja/sektor, dan sistem yang lebih luas untuk melaksanakan fungsi-fungsi mereka dan mencapai tujuan pembangunan yang telah ditetapkan dari waktu ke waktu. Selanjutnya, UNDP dan Canadian Intermational Development Agency (CIDA) dalam Milen (2006, h.15) memberikan pengertian pengembangan kapasitas sebagai proses dimana individu, kelompok, organisasi, institusi, dan masyarakat meningkatkan kemampuan mereka untuk menghasilkan kinerja pelaksanaan tugas pokok dan fungsi (core functions), memecahkan permasalahan, merumuskan dan mewujudkan pencapaian tujuan yang telah ditetapkan, dan memahami dan memenuhi kebutuhan pembangunan dalam konteks yang lebih luas dalam cara yang berkelanjutan.

\section{Dimensi dan Tingkatan Pengembangan Kapasitas}

GTZ (Deutsche Gesellschaft fur Technische Zusammenarbeit) dalam Milen (2006, h.22) menggambarkan bahwa dalam proses pengembangan kapasitas terdapat tiga tingkatan yang menjadi fokus analisis dan proses perubahan dalam suatu organisasi, meliputi:

a. Tingkatan sistem, suatu organisasi harus melakukan upaya proses perbaikan pada sistem, kebijakan, dan berbagai aturan yang menjadi dasar berbagai program, aktivitas, dan kegiatan pada organisasi. Dalam 
pengembangan kualitas sistem ini, yang menjadi fokus utama yaitu perubahan pada kebijakan dan peraturan yang dianggap menghambat kinerja optimal organsasi.

b. Tingkatan organisasi, upaya pengembangan kapasitas (capacity building) berhubungan dengan menciptakan perangkat struktur, kultur, dan pengelolaan organisasi yang mendukung para pegawai/individu untuk menunjukkan kinerja terbaiknya. Organisasi terdiri dari dua unsur utama, yaitu unsur perangkat keras (hardware) organisasi meliputi infrastruktur (gedung), struktur organisasi, serta dukungan anggaran, dan unsur perangkat lunak (software) organisasi adalah kultur organisasi, prosedur kerja, dan sumberdaya informasi.

c. Tingkatan individu adalah individu sebagai sumberdaya manusia organisasi yang harus ditingkatkan kemampuan dan profesionallismenya, baik pengetahuan, kompetensi, ketrampilan, maupun etika kerja.

\section{Faktor-faktor yang Mempengaruhi Pengembangan Kapasitas}

Menurut Warsito dan Yuwono (2003, h.6), faktor yang mempengaruhi program pengembangan kapasitas, meliputi:

a. Komitmen Bersama (Collective Commit-ments) Penguatan kapasitas memerlukan komitmen jangka panjang dari semua pihak yang terlibat dan menjadi modal dasar yang harus terusmenerus ditumbuhkembangkan dan dipelihara secara baik. Komitmen ini meliputi seluruh komponen yang ada dalam organisasi.

b. Kepemimpinan yang Kondusif (Condusive Leadership)

Dalam konteks lingkungan organisasi publik, harus didorong kepemimpinan yang dinamis untuk mengatasi tantangan ke depan yang semakin berat dan realitas keterbatasan sumberdaya yang dimiliki sektor publik. Kepemimpinan kondusif membuka kesempatan yang luas bagi setiap elemen organisasi untuk menyelenggarakan pengembangan kapasitas.

\section{c. Reformasi Peraturan}

Dalam sebuah organisasi hanus disusun peraturan yang mendukung upaya pengembangan kapasitas dan dilaksanakan secara konsisten.

\section{d. Reformasi Kelembagaan}

Reformasi kelembagaan menunjuk kepada bagian struktural dan kultural. Maksudnya adalah adanya budaya kerja yang mendu-kung pengembangan kapasitas.

e. Pengakuan Kekuatan dan Kelemahan yang Dimiliki. Mengidentifikasi kekuatan dan kelemahan agar dapat disusun program pengembangan kapasitas yang baik.

\section{Hambatan Pengembangan Kapasitas}

Menunut Yuwono dalam Warsito dan Yuwono (2003, h.9-10) menyebutkan hambatan capacity building ada lima di antaranya adalah:

a. Resistensi legal-prosedur, biasanya diguna-kan oleh pihak-pihak yang tidak mendukung program pengembangan kapasitas dengan berbagai alasan.

b. Resistensi dari pemimpin, khususnya supervisor ini mendasarkan diri pada argumen bahwa dengan pengembangan kapasitas, maka mau tidak mau kemampuan staf akan meningkat dan bisa saja memicu kedudukan struktural mereka.

c. Resistensi dari staf. Hambatan yang paling utama adalah bahwa pengembangan kapasitas merupakan sebuah inovasi atas perubahan, sehingga mereka harus melakukan perubahan atau usaha-usaha inovatif. Mungkin ada sebagian staf yang kurang dinamis dan tidak positif menyambut perubahan, sehingga berdampak negatif terhadap program pengembangan kapasitas tersebut.

d. Resistensi konseptual, muncul karena program pengembangan kapasitas menimbulkan pekerjaan dan beban yang harus ditanggung oleh semua elemen yang ada dalam organisasi tersebut. Mereka berpendapat bahwa dengan 
lebih efektif akan menambah beban kerja mereka, padahal beban kerja ini tentu berkorelasi positif dengan penambahan upah.

e. Resistensi berupa mispersepsi yaitu mispersepsi bahwa pengembangan kapasitas akan menimbulkan self capacity building. Artinya kemampuan individu menjadi diagungkan tanpa melihat aspek-aspek lainnya, padahal koordinasi, kooperasi, kolaborasi, kerjasama dan berbagai eleman dalam organisasi tersebut sangat menentukan keberhasilan program pengembangan kapasi-tas dalam sebuah organisasi, ini merupakan persepsi yang kelinu yang sering terjadi dalam konteks keorganisasian.

\section{GoodGovernance}

Good Governance mengandung dua makna seperti yang diungkapkan Mindarti (2007, h.182):

"Pertama, mengandung makna tentang orientasi ideal negara yang diarahkan pada pencapaian tujuan negara. Berorientasikan pada nilai-nilai yang menjunjung tinggi kehendak rakyat dan nilai-nilai yang dapat meningkatkan kemampuan rakyat dalam kemandirian, pembangunan berkelanjutan, keadilan sosial, demokratisasi dalam kehidupan bernegara seperti legitimasi, akuntabilitas, perlindungan HAM, otonomi, dan devolusi kekuasaan, pemberdayaan masyarakat sipil, dan sebagainya. Kedua, mengandung makna tentang aspek-aspek fungsional pemerintahan yang efektif dan efisien, atau pemerintahan yang berfungsi ideal, yaitu mampu berfungsi secara efektif dan efisien dalam upaya pencapaian tujuan nasional, hal ini aka sangat tergantung kepada sejauh mana pemerintahan mempunyai kompetensi serta sejauh mana struktur dan mekanisme politik dan administratif mampu berfungsi secara efektif dan efisien."

\section{Prinsip-prinsip Good Governance}

UDNP dalam Mindarti (2007, h.184), memformulasikan prinsip utama untuk mewujudkan good govemance, antara lain: a. Participation, keterlibatan masyarakat dalam pembuatan kebijakan, baik secara langsung maupun tidak langsung melalui lembaga perwakilan yang dapat menyalurkan aspirasinya.

b. Rule of Law, kerangka hukum yang adil dan dilaksanakan tanpa pandang bulu.

c. Transparency, adanya keterbukaan yang dibangun atas dasar kebebasan memperoleh informasi. Informasi yang berkaitan dengan kepentingan publik dapat diperoleh secara langsung dan tepat waktu bagi yang membutuhkan.

d. Responsiveness, lembaga-lembaga publik harus cepat dan tanggap dalam melayani stakeholder.

e. Consensus orientation, berorientasi pada kepentingan masyarakat yang lebih luas.

f. Equity, setiap masyarakat memiliki kesempatan yang sama untuk memperoleh kesejahteraan dan keadilan.

g. Efficiency and effectiveness, pengelolaan sumberdaya publik dilakukan secara berdaya guna dan berhasil guna.

h. Accountability, pertanggungjawaban kepada publik atas setiap aktivitas yang dilakukan.

i. Strategy vision, penyelenggaraan pemerintahan dan masyarakat harus memiliki visi jauh ke depan.

\section{Capacity Building Menuju Good Governance}

Menurut Yuwono dalam Warsito dan Yuwono (2003, h.14-15), salah satu hal dasar yang patut dimengerti dan disadari bersama dalam konteks pengembangan kapasitas adalah bahwa capacity building merupakan alat, teknik, atau metode yang digunakan dalam peningkatan pelayanan publik menuju pada perwujudan tata pemerintahan yang baik (good governance). Hal ini berarti bahwa capacity building harus dipahami sebagai sebuah fasilitasi yang sangat memungkinkan untuk mewujudkan tujuan akhir penyelenggaraan pemerintahan yaitu kesejahteraan masyarakat. Dengan demikian, maka program-program yang dicanangkan dalam 
program pengembangan kapasitas didasarkan pada pengabdian, pelayanan, dan demokratisasi dalam penyelenggaraan pemerintahan. Hal ini sangat penting bukan saja untuk menumbuhkan profesionalisme penyelenggaraan pemerintahan, akan tetapi juga berorientasi pada dasar-dasar good governance.

\section{Metode Penelitian}

Jenis penelitian yang digunakan ialah deskriptif dengan pendekatan kualitatif. Bogdan dan Taylor dalam Moleong (2014, h.4) mendefinisikan metodologi kualitatif sebagai prosedur penelitian yang menghasilkan data deskriptif berupa kata-kata tertulis atau lisan dari orang-orang dan perilaku yang dapat diamati. Dengan kata lain, penelitian ini disebut penelitian kualitatif karena merupakan penelitian yang tidak mengadakan perhitungan.

Fokus penelitian ini adalah (1) upaya pengembangan kapasitas pegawai di Dinas Kepemudaan dan Olahraga Kota Palembang melalui a) peningkatan pengetahuan dan ketrampilan pegawai, b) pembentukan etika dan kedisiplinan pegawai. (2) Penerapan prinsip-prinsip good governance meliputi a) transparansi, b) responsivitas, c) keadilan. (3) Faktor-faktor yang mendukung dan menghambat pengembangan kapasitas pegawai di Dinas Kepemudaan dan Olahraga Kota Palembang.

Lokasi penelitian adalah di Kota Palembang dan situs penelitian di Badan Kepegawaian Dan Pengembangan Sumber Daya Manusia (Dinas Kepemudaan dan Olahraga) Kota Palembang. Sumber data diperoleh dari data primer dan sekunder. Pengumpulan data dilakukan melalui wawancara, observasi, dan dokumentasi. Analisis data menggunakan model analisa interaktif oleh Miles, Hubberman, dan Saldana (Saldana, 2013, h.14) melalui empat tahap yaitu pengumpulan data, kondensasi data, penyajian data, dan kesimpulan.

\section{Pembahasan}

\section{Upaya Pengembangan Kapasitas Pegawai Internal Dinas Kepemudaan dan Olahraga KotaPalembang}

Menunut teori GTZ dalam Milen (2006, h.22) bahwa dalam tingkatan atau dimensi capacity building, terdapat salah satu dimensi yang memfokuskan pada pengembangan sumberdaya manusia. Dimana, dalam teori tersebut menyatakan bahwa pada tingkatan pengembangan individu yang perlu dikembangkan adalah pengetahuan dan ketrampilan, serta pembentukan etika dan disiplin pegawai.

\section{a. Peningkatan Pengetahuan dan Ketrampilan Pegawai}

\section{1) Pendidikan dan Pelatihan (Diklat)}

\section{a) Dikat Struktural/DiklatPim}

Peningkatan pengetahuan dan ketrampilan pegawai di Dinas Kepemudaan dan Olahraga Kota Palembang diupayakan dengan mengikutsertakan pegawai pada kegiatan Diklat, terutama Diklat Struktural/DiklatPim. Diklat Struktural ini wajib dilaksanakan bagi pegawai yang akan mengembangkan kariemya dengan menduduki jabatan struktural yang lebih tinggi.

Jabatan struktural yang lebih tinggi dengan beban tugas dan tanggung jawab yang lebih besar. Sehingga kemudian perlu dilaksanakan diklat untuk meningkatkan kemampuan pegawai tersebut, sehingga dapat menjalankan tupoksinya dengan baik dan profesional.

Setelah dilaksanakan diklat, para pegawai Dinas Kepemudaan dan Olahraga Kota Palembang memiliki keahlian yang lebih, baik pengetahuan, ketrampilan, dan wawasan untuk menunjang kinerja pegawai. Sehingga, dapat meningkatkan hasil kinerja yang baik dalam rangka untuk mencapai tujuan organisasi. Sedangkan bagi individunya sendiri dapat menambah rasa percaya diri dalam menyelesaikan masalah beban pekerjaan yang sebelumnya belum dapat ditangani, setelah mengikuti diklat, bisa menyelesaikan 
masalah pekerjaan, contohnya dalam pembuatan renstra. Di samping itu, pegawai mampu mengambil keputusan melalui pertimbangan yang baik. Hal ini sesuai dengan pendapat Siagian (2005:184) bahwa manfaat yang didapat oleh para pegawai suatu organisasi setelah dilakukan program pengembangan kapasitas, baik bagi organisasi maupun bagi individu pegawai itu sendiri.

\section{b) Diklat Fungsional dan Teknis}

Diklat Teknis merupakan diklat yang diarahkan untuk membentuk tenaga teknis yang profesional. Diklat fungsional lebih dilaksanakan pada peningkatan keahlian seseorang pegawai sehingga dapat menjalankan tupoksinya dengan progesional dan berkompeten, terutama dalam memberikan pelayanan prima kepada para stakehorlders sebagai wujud melaksanakanpenyelenggaraan pemerintahan yang baik. Terdapat 2 pegawai Dinas Kepemudaan dan Olahraga Kota Palembang yang telah mengikuti Diklat Fungsional tentang Keuangan daerah. Hal ini menunjukkan bahwa Dinas Kepemudaan dan Olahraga Kota Palembang benar-benar serius dalam mengupayakan peningkatan pengetahuan, kemampuan, dan ketrampilan teknis pegawai intemalnya.

Pegawai yang mengikuti diklat harus diseleksi terlebih dahulu oleh pimpinan SKPD, kemudian diajukan kepada Badan Diklat Kota Palembang. Dinas Kepemudaan dan Olahraga Kota Palembang memiliki standarisasi tertentu yang dapat digunakan sebagai pedoman dalam menyeleksi pegawai yang memang layak diikutsertakan dalam program diklat. Sehingga upaya yang dilakukan oleh Dinas Kepemudaan dan Olahraga Kota Palembang untuk mengembangkan kemampuan dan keahlian pegawainya memberikan manfaat bagi peningkatan pengetahuan dan ketrampilan pegawai tersebut.

\section{2)Pendidikan Formal}

\section{a) Tugas Belajar}

Tugas Belajar ini merupakan salah satu upaya yang ditempuh Dinas Kepemudaan dan Olahraga Kota Palembang untuk mengembangkan dan meningkatkan kemampuan dan profesionalisme pegawai dengan meningkatkan pengetahuan dan ketrampilannya. Antusiasme pegawai cukup baik dalam merespon program ini karena memang pada dasamya tugas belajar ini pegawai tidak mengeluarkan biaya pendidikan karena sudah dianggarkan oleh pihak yang menyelenggarakan melalui beasiswa oleh pihak-pihak tertentu, seperti perusahaan milik pemerintah dan kementerian-kementerian melalui biaya APBD sebagai bentuk reward. Terlebih lagi, jika pegawai mengikuti Tugas Belajar ini maka pegawai dibebastugaskan dari pekerjaan atau tupoksi yang sedang diemban karena tugas belajar ini dilaksanakan pada waktu jam kerja.

\section{b) Ijin Belajar}

Ijin Belajar yang diikuti oleh pegawai intemal Dinas Kepemudaan dan Olahraga Kota Palembang yang sedang atau akan menduduki jabatan struktural yang lebih tinggi dimaksudkan sebagai upaya peningkatan pengetahuan dan ketrampilan pegawai dengan melanjutkan pendidikan ke jenjang yang lebih tinggi. Terdapat 3 pegawai internal Dinas Kepemudaan dan Olahraga Kota Palembang yang telah mengikuti ljin Belajar pada tahun 2013. Hal ini dapat mendorong semangat pegawai dalam menjalankan kinerjanya, sehingga pegawai mampu menjalankan tupoksi secara optimal dan profesional. Jika pegawai memiliki semangat dan antusiasme yang tinggi untuk melaksanakan tugas pekerjaannya, maka pegawai tersebut memiliki kecendenungan untuk menyelesaikan pekerjaan seoptimal mungkin. Ketika aparatur mampu melaksanakan tupoksinya, terutama dalam melaksanakan penyelenggaraan pemerintahan kaitannya dengan pelayanan prima. Pada akhimya, penyelenggaraan pemerintahan yang baik dan profesional akan terwujud sesuai dengan prinsip-prinsip good governance. 


\section{3) Pelatihan Pegawai}

Upaya pengembangan kapasitas pegawai intemal Dinas Kepemudaan dan Olahraga Kota Palembang dilakukan dengan mengikuti berbagai pelatihan yang diselenggarakan oleh pihak luar Dinas Kepemudaan dan Olahraga, baik dari pemerintah pusat, provinsi, maupun lembagalembaga tertentu. Pelatihan ini dimaksudkan untuk meningkatkan pengetahuan, wawasan, dan ketrampilan pegawai untuk menunjang pegawai dalam melaksanakan tugas pokok dan fungsi yang diemban agar mampu menghasilkan kinerja yang baik dan profesional sesuai dengan capaian atau target kinerja. Sesuai dengan teori danCanadian International Development Agency (CIDA) dalam Milen (2006, h.15), bahwa pengembangan kapasitas sebagai proses dimana individu meningkatkan kemampuan mereka untuk menghasilkan kinerja pelaksanaan tugas pokok dan fungsi (core function) dan mewujudkan pencapaian tujuan yang telah ditetapkan.

Pelatihan yang pernah diikuti oleh para pegawai Dinas Kepemudaan dan Olahraga Kota Palembang meliputi kegiatan workshop, BIMTEK, dan sosialisasi atau rapat intemal dari pihak Dinas Kepemudaan dan Olahraga sendiri. Para pegawai yang mengikuti pelatihan tersebut disesuaikan dengan tupoksi pegawai yang bersangkutan. Kegiatan pelatihan workshop dan BIMTEK tidak sepenuhnya memberikan manfaat bagi pegawai yang mengikutinya. Pelatihan BIMTEK Keuangan yang telah diikuti oleh kedua pegawai Dinas Kepemudaan dan Olahraga Kota Palembang juga tidak sepenuhnya berpenganuh terhadap kinerja pegawai, terutama dalam hal sistem pengelolaan keuangan. Hal ini dikarenakan sistem keuangan di Dinas Kepemudaan dan Olahraga Kota Palembang hanya berbentuk pelaporan saja yang telah diproses melalui sistem aplikasi SIMDA, sehingga tidak membawa perubahan terhadap pengelolaan keuangan. Di samping itu, karena tidak ada bendahara penerimaan, yang ada hanya bendahara pengeluaran. Sehingga, tidak ada sistem pengelolaan keuangan yang sangat krusial.

\section{b. Pembentukan Etika dan Kedisiplinan Pegawai}

Secara normatif Dinas Kepemudaan dan Olahraga Kota Palembang berpedoman pada PP Nomor 53 Tahun 2010. Kedisiplinan pegawai Dinas Kepemudaan dan Olahraga Kota Palembangjika dilihat dari aspek pelanggaran pegawai selama ini hanya terdapat pelanggaran yang ringan-ringan saja, tidak ada pegawai intemal Dinas Kepemudaan dan Olahraga Kota Palembangyang terlibat kasus sampai ke ranah hukum. Berkaitan dengan pelanggaran yang telah dilakukan oleh salah satu pegawai internalnya, yakni tidak masuk kerja selama 19 hari tanpa keterangan sehingga pihak Dinas Kepemudaan dan Olahraga harus melakukan mutasi terhadap pegawai tersebut dengan persetujuan Bupati. Berdasarkan PP Nomor 53 Tahun 2010, pelanggaran seperti ini temasuk ke dalam kategori pelanggaran disiplin sedang. Dalam Pasal 9 Ayat (11) huruf a, menerangkan bahwa PNS yang tidak masuk kerja tanpa alasan yang sah selama 16-20 hari kerja, maka diberikan sanksi berupa penundaan kenaikan gaji berkala selama 1 (satu) tahun.

Dapat diketahui bahwa Dinas Kepemudaan dan Olahraga belum sepenuhnya berpedoman pada PP Nomor 53 Tahun 2010. Karena pemberian sanksi terhadap pegawai tidak sepenuhnya sesuai dengan ketentuan hukuman yang telah ditetapkan dalam peraturan pemerintah tersebut. Dimana, sanksi yang sehanusnya diberikan adalah berupa penundaan kenaikan gaji berkala selama satu tahun, tetapi pihak Dinas Kepemudaan dan Olahraga Kota Palembang justru memberikan sanksi berupa mutasi ke instansi lain, meskipun melalui persetujuan walikota.

\section{Penerapan Prinsip-prinsip Good Governance di Dinas Kepemudaan dan Olahraga Kota Palembang}

\section{a. Transparansi Pegawai}


Penerapan transparansi pegawaiBKPSDM Kota Palembang, dimana pegawai dituntut agar selalu memberikan berbagai informasi kepada masyarakat yang membutuhkan, terutama PNS Kota Palembang itu sendiri. Hal ini telah dilaksanakan oleh Dinas Kepemudaan dan Olahraga Kota Palembang, dimana dalam memberikan informasi telah tertuang dalam Website resmi Dinas Kepemudaan dan Olahraga Kota Palembang, serta media cetak seperti membuat buku profil organisasi. Di sisi lain, pegawai Dinas Kepemudaan dan Olahraga Kota Palembang, terutama Bidang Informasi Kepegawaian juga mengupayakan pemberian informasi melalui kegiatan sosialisasi, namun rencana kegiatan tersebut selalu terhambat di tengah jalan yang disebabkan oleh beberapa faktor, sehingga pelaksanaan sosialisasi tidak dapat terealisasikan dengan baik.

\section{b. ResponsivitasPegawai}

Para pegawai Dinas Kepemudaan dan Olahraga Kota Palembang menunjukkan bentuk responsivitasnya dengan berusaha memberikan pelayanan sesuai SOP dan SPP yang ada, sehingga para pegawai berusaha mencapai target tersebut. Jadi, pegawai selalu mengusahakan memberikan pelayanan seresponsif mungkin, tanpa menunda dan berbelit-belit. Hal ini tentu memberikan dampak positif terhadap penyelenggaraan tata pemerintahan yang baik (good governance), secara otomatis responsivitas pegawai Dinas Kepemudaan dan Olahraga Kota Palembangdalam memberikan pelayanan selalu memberikan kemudahan bagi stakeholders.

\section{c. Keadilan}

Prinsip keadilan yang diterapkan oleh pegawai Dinas Kepemudaan dan Olahraga Kota Palembang berdasar pada Standar Operasional Prosedur yang sudah ditetapkan. Pegawai tidak memandang seseorang yang dilayani berdasarkan agama, ras, suku, golongan, jabatan maupun kerabatnya. Ketika ada PNS Daerah yang tidak memiliki kelengkapan berkas administrasi, pegawai Dinas Kepemudaan dan Olahraga tidak memberikan pengecualian karena semua PNS Daerah memiliki hak yang sama, tidak ada diskriminasi. Hal ini tentu memberikan dampak positif terhadap PNS Daerah Kabupaten Malang maupun masyarakat lainnya, seperti kepuasan pelayanan dan tidak adanya rasa diskriminasi.

\section{Faktor Pendukung dan Penghambat dalam Pengembangan Kapasitas Pegawai di Dinas Kepemudaan dan Olahraga Kota Palembang a. Faktor Pendukung \\ 1) Kepemimpinan}

Pimpinan Dinas Kepemudaan dan Olahraga Kota Palembang bersikap kondusif dan bijak dalam kaitannya dengan pengembangan kapasitas. Hal tersebut dapat dilihat dari hasil penelitian bahwa Kepala Dinas Kepemudaan dan Olahraga Kota Palembang menunjuk pegawai untuk mengikuti diklat formal yang disesuaikan dengan jabatan struktural, pelatihan-pelatihan disesuaikan dengan bidang dan tupoksi pegawai, serta melakukan penilaian tertentu terhadap masing-masing pegawai melalui sistem penilaian kinerja apakah pegawai tersebut perlu dilaksanakan pengembangan kapasitas atau tidak.

\section{2) Komitmen Bersama}

Komitmen bersama yang dibuat diawali dari kedudukan dan fungsi setiap pegawai. Dimana masing-masing pegawai memiliki kontrak kerja yang dijadikan komitmen oleh semua pegawai Dinas Kepemudaan dan Olahraga Kota Palembang. Dimana kontrak kerja ini menjadi capaian kinerja pegawai sesuai dengan tupoksi masing-masing pegawai.

\section{b. Faktor Penghambat}

\section{1) Kesadaran Individu Pegawai}

Berdasarkan teori Warsito dan Yuwono (2003:9), bahwa hambatan paling utama dalam capacity building adalah resistensi dari staf. Kesadaran pegawai Dinas Kepemudaan dan Olahraga Kota Palembang akan pentingnya upaya 
pengembangan kapasitas pegawai memang variatif, dimana ada beberapa pegawai yang sangat respon positif, namun ada pula pegawai yang kurang respon terhadap upaya pengembangan kapasitas pegawai. Hal ini disebabkan pegawai kurang memiliki keinginan dan motivasi untuk melakukan pengembangan yang nantinya akan menghasilkan perubahan dan inovasi. Beberapa pegawai memang masih stagnan dan hanya ingin fokus terhadap beban tugas di bidangnya, serta tidak ingin memiliki beban kerja yang lebih.

\section{Kesimpulan}

Berdasarkan pembahasan di atas dapat disimpulkan bahwa sudah ada upaya pegembangan kapasitas pegawai untuk mewujudkan good governance di Dinas Kepemudaan dan Olahraga Kota Palembang. Namun upaya tersebut tidak sepenuhnya berpenganuh terhadap penerapan prinsip-prinsip good governance itu sendiri. Hal ini karena terdapat faktor penghambat dalam upaya pengembangan kapasitas pegawai yaitu kesadaran individu pegawai itu sendiri. Oleh karena itu perlu adanya kebijakan pimpinan dan pemberlakuan teknik social engineering untuk mengeliminasi resistensi pengembangan kapasitas pegawai.

\section{Daftar Pustaka}

Artika, Indah J.N. (2014) Pengembangan Kapasitas Sumberdaya Aparatur Dalam Rangka Meningkatkan Kinerja. S.AP.skripsi, Universitas Brawijaya Malang.

Dian, Endra Prasetia. 2014. Upaya Meningkatkan Kualitas Sumberdaya Aparatur. S.AP.skripsi, Universitas Brawijaya Malang.

Indah, Lely Mindarti. (2007) Revolusi Administrasi Publik: Aneka Pendekatan dan Teori Dasar. Malang, Bayumedia Publishing.
Milen, Anneli. (2006) Capacity Building Meningkatkan Kinerja Sektor Publik. Yogyakarta, Pembaruan.

Moleong, Lexy J. (2014) Metodologi Penelitian Kualitatif. Bandung, PT Remaja Rosdakarya.

Saldana, Johnny, et. al. (2013) Qualitative Data Analysis: A Methods Sourcebook. Washington DC, SAGEPublication, Inc.

Siagian, Sondang P. (2005) Manajemen Sumberdaya Manusia. Jakarta, Bumi Aksara.

Sjamsuddin, Sjamsiar Indradi. (2010) Dasardasar dan Teori Administrasi Publik Malang, Agritek YPN.

Thoha, Miftah. (2008) Ilmu Administrasi Publik Kontemporer. Jakarta, Kencana.

Warsito dan Yuwono, Teguh. (2003) Otonomi Daerah Capacity Building dan Penguatan Demokrasi aLokal. Semarang, Puskodak(CloG 